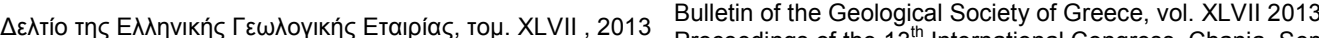
Proceedings of the $13^{\text {th }}$ International Congress, Chania, Sept.

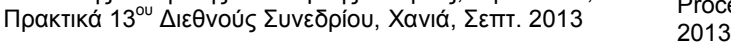

\title{
ENVIRONMENTAL PRESSURES TO THE WATER RESOURCES IN THE WIDER AREA OF RODITSA, IN SPERCHIOS RIVER DELTA OF EASTERN CENTRAL GREECE
}

\author{
Katsifa M. ${ }^{1}$, Koumantakis I. $^{2}$, Stathopoulos N. ${ }^{2}$ and Vasileiou E. ${ }^{2}$ \\ ${ }^{1}$ Msc in Water Resources Science and Technology (WRST) NTUA, Civil Engineer N.Chochlia 13 \\ Roditsa, 35100,Lamia,mkatsifa@hotmal.com \\ ${ }^{2}$ National Technical University of Athens, School of Mining Engineering \& Metallurgy, Section of \\ Geological Sciences, Laboratory of Engineering Geology \& Hydrogeology, Iroon Polytechneiou \\ 9, Athens15780koumantakisioannis@gmail.com,nstath@metal.ntua.gr,elvas@metal.ntua.gr
}

\begin{abstract}
The aim of this paper is to describe the "pressures" in the water environment, focusing in the water quality regime. The study area is located in the east-southeast of Lamia, southwest of the mountain Orthris, up to Maliakos gulf. The groundwater quality, regarding its irrigative use, ranges between good and moderate. The main sources of water deterioration are agricultural activities and sea intrusion near the coastline. Similar conditions are observed in the surface water of the area. Concerning the qualitative suitability of the water for irrigation, in the majority of the area's surface water samples that were tested, there is a fluctuation between good and moderate. The hydrological data from the karstic springs were evaluated and several estimations were made, for describing their hydrodynamic regime. Certain proposals are suggested for the sustainable management of the water resources, concerning the proper use of the karstic springs and surface water, the reuse of sewage water, the exploitation of groundwater and a number of further actions that should be taken under consideration based on the European legislation

Key words: karstic springs, salinization, Maliakos gulf, irrigation.
\end{abstract}

\section{Пєрí $\lambda \psi \eta$}

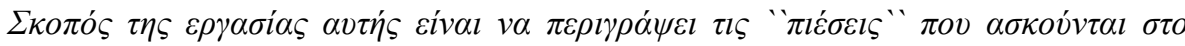

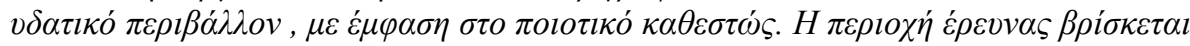

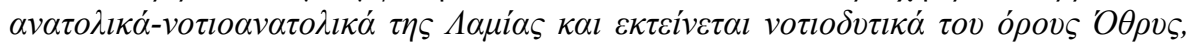

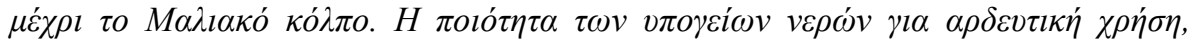

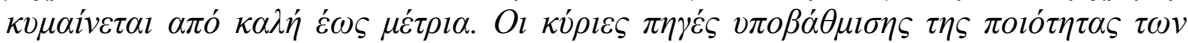

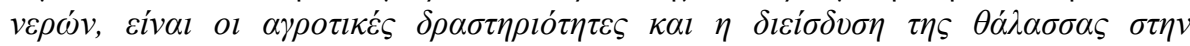

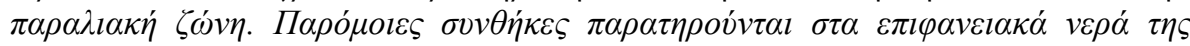

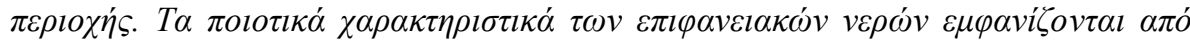

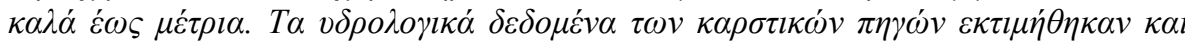

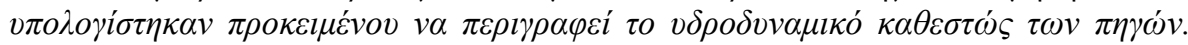

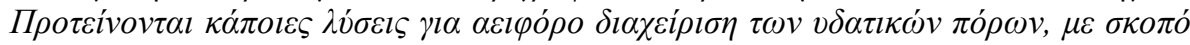

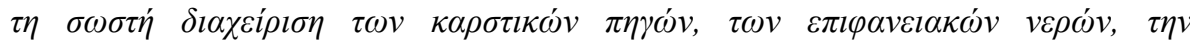

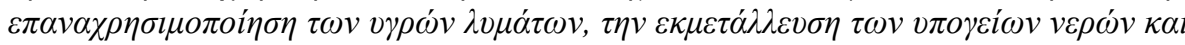

XLVII. No $2-702$ 


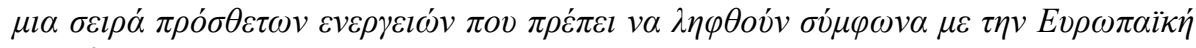

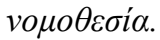

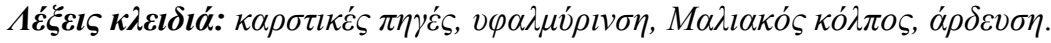

\section{Introduction}

The area of interest belongs to the water compartment of Eastern Central Greece and is located on the east - southeast side of Lamia city and southwest of Orthris Mountain. The area is part of Sperchios river delta, whose estuaries end up in Maliakos Gulf. Part of Maliakos Gulf shoreline is the eastern natural limit of the research area. The altitude of the area fluctuates between 0 and 4,5m, with small slopes that do not exceed 3\% (Papadimitriou N. 2010).

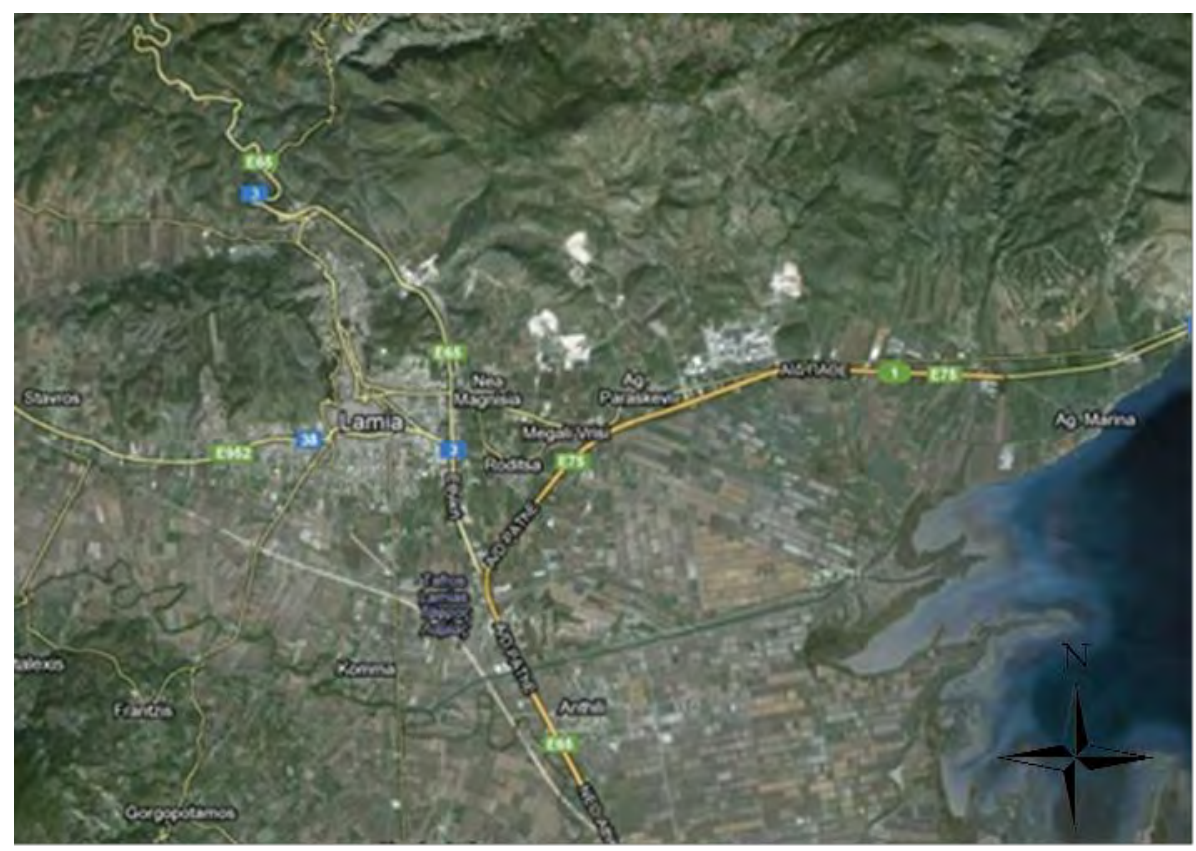

Figure 1 - Location of the study area.

\section{Materials and Methods}

\subsection{Geology-Hydrogeology}

Throughout the wider extent of the research area we find alluvial deposits. These geological formations are, either recent deposits coming from the sediment yield of Sperchios River and other local streams, or material coming from the mountainsides of Orthris of the same limestone and schist formations on which it is deposited.

The soil types that are found in the area, are intercalations of clay and clay-silts, with interjecting thin layers of sand, sand-silt and argillaceous sand with gravels. The succession and thickness of the intercalations differs per place.

The area is part of Sperchios river hydrological system and the aquifer system of Lamia. Hydrolithologically consists of deltaic alluvial deposits of Sperchios River, which consist of alternations of coarse and fine-grained materials. In the northern part of the area, in mountain Orthris frindge, Lamia's Karstic system is deployed. 
The composition of the alluvial deposits varies; they have high permeability and consist of unbound materials, pebble and breccia of various size, gravels- and sand that alternate with low permeability materials, such as clay and silts. The deployed aquifer system, due to these alternations, is separated in two individual confined aquifers and one unconfined (M.W.S.C.L., LRI - NAGREF, 2009).

The aquifer system of Lamia consists of karstified Upper-Cretaceous limestone that in its base is in contact with impermeable formations of the schist-crest conformation. This limestone aquifer discharges through Megali Vrusi, Sfageio and Mauromantila springs.

In the lowland part of the research area, due to variations in the granulometric gradation of recent deposits, confined and unconfined aquifers are deployed. The recharge of these aquifers is accomplished through water infiltration by the rivers and streams, through the direct infiltration in the detrital cone and in the coarse deposits of the lowland areas and to some extent by sideway transfusions of the karstic fringe towards the recent deposits of the lowland part.. In the low-level region there is a large number of boreholes and wells that are used mainly for irrigation purposes (Tsoumas V., Zorapas V. 2010).

The hydraulic conductivity and capacity of Lamia's karstic system varies. Specifically, in the area of Ag Paraskeui (where the springs of Megali Vrusi are found), the system is characterized of high capacity; while in the area of Mauromantila is of moderate to insignificant capacity (Dimitressas D. 1999).

In the eastern part, in Sperchios delta and near the shores of Maliakos Gulf, there are clay-silt formations with some layers of sand, which are found in small extent and limited thickness. These aquifers are of low capacity and are not suitable for productive drillings.

In the eastern fringes of Sperchios basin that surround the lowland deltaic area of the river, fanglomerates and detrital cones are deployed, formations with important aquifer dynamics, as well as karstic aquifers of high capacity (Tsoumas V., Zorapas V. 2010).

\subsection{Hydrodynamic Conditions}

In the area of interest there are many springs and the most important of them is Megali Vrusi spring. The following diagram (Figure 2) presents the monthly fluctuation (average, maximum, minimum) of the recharges of Megali Vrusi springs, for the time period $1961-2010$.

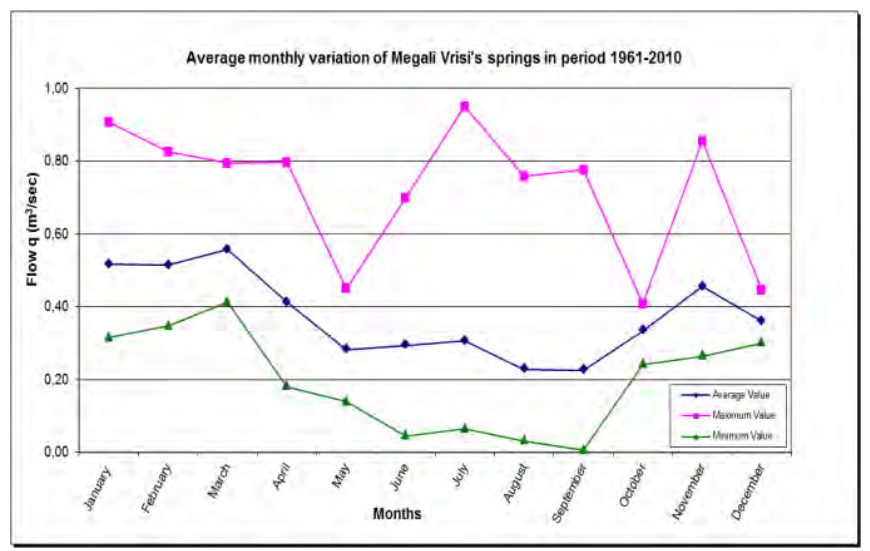

Figure 2 - Average monthly discharge in Megali Vrusi springs.

The irrigative needs of the area are mainly covered by the surficial water of Sperchios River. Due to the increased needs during the summer months, the irrigation of the crops, at the landredistribution zone of Roditsa, is carried out also with the exploitation of groundwater, through the six public drillings, but mainly through private drillings (at least 35 private drillings). 


\section{Water Quality of Research area}

For the research of the water quality status in the area, adequate sampling took place in selected points, simultaneously with the beginning of the irrigation period $(4-5 / 7 / 2011)$, both from the surficial recipients (Sperchios diversion, German moat, Ksirias, Megali Vrusi springs) and groundwater through the drillings.

Table 1 - Chemical analysis of Groundwater.

\begin{tabular}{|c|c|c|c|c|c|c|c|c|c|c|c|c|c|}
\hline \multirow[b]{2}{*}{ ID } & \multirow[b]{2}{*}{ Station ID } & \multicolumn{4}{|c|}{ Physical features - parameters } & \multicolumn{4}{|c|}{ Main Cations (mg/l) } & \multicolumn{4}{|c|}{ Main Anions (mg/l) } \\
\hline & & $\mathrm{T}\left({ }^{\circ} \mathrm{C}\right)$ & $\mathrm{PH}$ & E.C. $(\mu \mathrm{S} / \mathrm{cm})$ & $\operatorname{TDS}(\mathrm{mg} / \mathrm{l})$ & $\mathrm{Ca}^{++}$ & $\mathrm{Mg}^{++}$ & $\mathrm{Na}^{++}$ & $\mathrm{K}^{++}$ & $\mathrm{HCO}_{3}^{-}$ & $\mathrm{Cl}^{-}$ & $\mathrm{SO}_{4}^{-}$ & $\mathrm{NO}_{3}^{-}$ \\
\hline $\mathrm{G} 2$ & Mavromadila & 19,7 & 7,2 & 624 & 406 & 98 & 3 & 19 & 2 & 289 & 30 & 7 & 25,1 \\
\hline G3 & Agia Paraskevi & 18,4 & 7,4 & 582 & 378 & 90 & 24 & 14 & 1 & 307 & 25 & 23 & 62,7 \\
\hline G4 & Stergiopoulou & 18,4 & 7,8 & 1492 & 970 & 128 & 32 & 159 & 32 & 199 & 351 & 54 & 31,6 \\
\hline G5 & Xatzikosta & 18,3 & 8 & 294 & 191 & 34 & 2 & 15 & 1 & 167 & 21 & 15 & 13,9 \\
\hline G6 & Tsaina & 18,4 & 8,1 & 442 & 287 & 17 & 1 & 38 & 2 & 231 & 54 & 24 & 38,8 \\
\hline G7 & Ftelies & 18,1 & 8 & 358 & 233 & 65 & 1 & 8 & 1 & 268 & 10 & 7 & 1 \\
\hline G8 & Zardas a & 18,1 & 8 & 711 & 462 & 28 & 6 & 6 & 1 & 423 & 7 & 1 & 3,2 \\
\hline G9 & Stathopoulos & 18,9 & 8,1 & 491 & 319 & 26 & 1 & 6 & 1 & 356 & 8 & 2 & 9,2 \\
\hline G10 & Kontos a & 18,7 & 7,9 & 429 & 279 & 44 & 11 & 5 & 1 & 277 & 5 & 3 & 15 \\
\hline G11 & Kontos b & 18,5 & 7,7 & 511 & 332 & 84 & 12 & 18 & 2 & 212 & 29 & 25 & 63,1 \\
\hline G12 & Agios Panteleimon & 18 & 7,6 & 604 & 393 & 113 & 15 & 17 & 1 & 312 & 23 & 23 & 48,6 \\
\hline G13 & Zardas b & 18,2 & 7,4 & 882 & 573 & 145 & 39 & 21 & 2 & 451 & 34 & 42 & 74,3 \\
\hline
\end{tabular}

Table 2 - Chemical analysis of Surface water.

\begin{tabular}{|c|c|c|c|c|c|c|c|c|c|c|c|c|c|}
\hline \multirow[b]{2}{*}{ ID } & \multirow{2}{*}{ Station ID } & \multicolumn{4}{|c|}{ Physical features - parameters } & \multicolumn{4}{|c|}{ Main Cations (mg/l) } & \multicolumn{4}{|c|}{ Main Anions (mg/l) } \\
\hline & & $\mathrm{T}\left({ }^{\circ} \mathrm{C}\right)$ & $\mathrm{PH}$ & E.C. $(\mu \mathrm{S} / \mathrm{cm})$ & TDS (mg/l) & $\mathrm{Ca}^{++}$ & $\mathrm{Mg}^{++}$ & $\mathrm{Na}^{++}$ & $\mathrm{K}^{++}$ & $\mathrm{HCO}_{3}^{-}$ & $\mathrm{Cl}^{-}$ & $\mathrm{SO}_{4}^{-}$ & $\mathrm{NO}_{3}$ \\
\hline Th1 & Before dam & 20,4 & 7,7 & 487 & 317 & 83 & 17 & 21 & 4 & 275 & 13 & 39 & 8,4 \\
\hline Th2 & Cross Spercheos - canal T1 & 21,1 & 8 & 485 & 315 & 83 & 15 & 20 & 4 & 265 & 11 & 38 & 13,2 \\
\hline Th3 & German Trench before Ksirias riverbed & 21,2 & 7,7 & 981 & 638 & 96 & 65 & 26 & 5 & 540 & 25 & 69 & 26,1 \\
\hline Th4 & Ksirias riverbed before German Trench & 23,2 & 8,1 & 372 & 242 & 47 & 19 & 21 & 4 & 218 & 14 & 23 & 13,7 \\
\hline Th5 & Soil trench before the canal leading to Roditsa & 20 & 8 & 470 & 306 & 83 & 15 & 23 & 4 & 271 & 17 & 42 & 16,8 \\
\hline Th6 & German Trench before Biological Treatment & 21,4 & 8 & 596 & 387 & 64 & 39 & 24 & 5 & 345 & 19 & 33 & 6,6 \\
\hline Th7 & Springs of Megali Vrisi & 18,4 & 7,3 & 567 & 369 & 91 & 14 & 24 & 5 & 287 & 21 & 11 & 38,5 \\
\hline Th8 & Pumping - station & 23,7 & 7,6 & 4700 & 3055 & 103 & 106 & 517 & 168 & 331 & 1224 & 200 & 6,9 \\
\hline Th9 & New riverbed - exit to Maliakos Gulf & 23,4 & 7,9 & 1864 & 1212 & 86 & 48 & 177 & 55 & 276 & 393 & 95 & 7,8 \\
\hline Th10 & German trench after Biological treatment & 25,1 & 7,8 & 882 & 573 & 74 & 24 & 34 & 8 & 433 & 44 & 37 & 6,2 \\
\hline Th11 & New riverbed - before German trench & 21,1 & 7,8 & 527 & 343 & 80 & 16 & 21 & 4 & 264 & 12 & 39 & 6,5 \\
\hline
\end{tabular}

Table 3: Water type of each sample.

\begin{tabular}{|c|c|c|}
\hline $\begin{array}{c}\text { ID } \\
\text { (Groundwater) }\end{array}$ & Station ID & HYDROCHEMICAL TYPE \\
\hline G2 & Mavromadila & $\mathrm{Ca}-\mathrm{HCO}{ }_{3}$ \\
G3 & Agia Paraskevi & Ca-Mg- $\mathrm{HCO}_{3}$ \\
G4 & Stergiopoulou & $\mathrm{Na}-\mathrm{Ca}-\mathrm{Cl}-\mathrm{HCO}_{3}$ \\
G5 & Xatzikosta & $\mathrm{Ca}-\mathrm{Na}-\mathrm{HCO}_{3}$ \\
G6 & Tsaina & $\mathrm{Na}-\mathrm{HCO}_{3}-\mathrm{Cl}$ \\
G7 & Ftelies & $\mathrm{Ca}-\mathrm{HCO}_{3}$ \\
G8 & Zardas a & $\mathrm{Ca}-\mathrm{HCO}_{3}$ \\
G9 & Stathopoulos & $\mathrm{Ca}-\mathrm{HCO}_{3}$ \\
G10 & Kontos a & $\mathrm{Ca}-\mathrm{Mg}-\mathrm{HCO}_{3}$ \\
G11 & Kontos b & $\mathrm{Ca}-\mathrm{HCO}_{3}$ \\
G12 & Agios Panteleimon & $\mathrm{Ca}-\mathrm{HCO}_{3}$ \\
G13 & Zardas b & $\mathrm{Ca}-\mathrm{Mg}-\mathrm{HCO}_{3}$ \\
\hline
\end{tabular}




\subsection{Groundwater Quality}

In Table 1 concerning groundwater, the water type $\mathrm{HCO}_{3}$ that appears in all the samples is clearly noticed and it could be attributed to the mineralogical composition of the various geological formations, through which the groundwater flows. These can be karstic formations (e.g. limestone), marl formations, or in general formations with many carbonic compounds, like for example the alluvial deposits.

In addition, the following lab results that came of the chemical analysis of the samples are worth mentioning:

- In the drilling $\mathrm{G} 4$, high concentrations of $\mathrm{Cl}(35 \mathrm{mg} / \mathrm{l})$ and $\mathrm{Na}(159 \mathrm{mg} / \mathrm{l})$ were measured, fact that implies salinization (Figure 3). The high concentrations of $\mathrm{Cl}^{-}$is due to the sea intrusion. There are not samples near the coastline; the blue dashed line is the actual limit of the measurements. The eastern part of this limit is a "false" picture of the Kriging method used by the Surfer software.

- In the drilling $\mathrm{G} 3$, high values of anions, $\mathrm{HCO}_{3}, \mathrm{Cl}, \mathrm{SO}_{4}$ and $\mathrm{NO}_{3}(62,7 \mathrm{mg} / \mathrm{l})$ were measured. The increased values of $\mathrm{Cl}, \mathrm{SO}_{4}, \mathrm{HCO}_{3}$, are probably due to wring leakage from the sanitary landfill waste area or/and from the cemetery, that neighbours with the drilling (the cemetery $50 \mathrm{~m}$ west and Lamia's waste disposal area 2,5 km northwest of the drilling). The geological background of the area favours this possible hydraulic communication. The increased values of $\mathrm{NO}_{3}$ have as possible sources the wrings of the neighbouring cemetery, the fertilizers or/and the livestock wastes of the area.

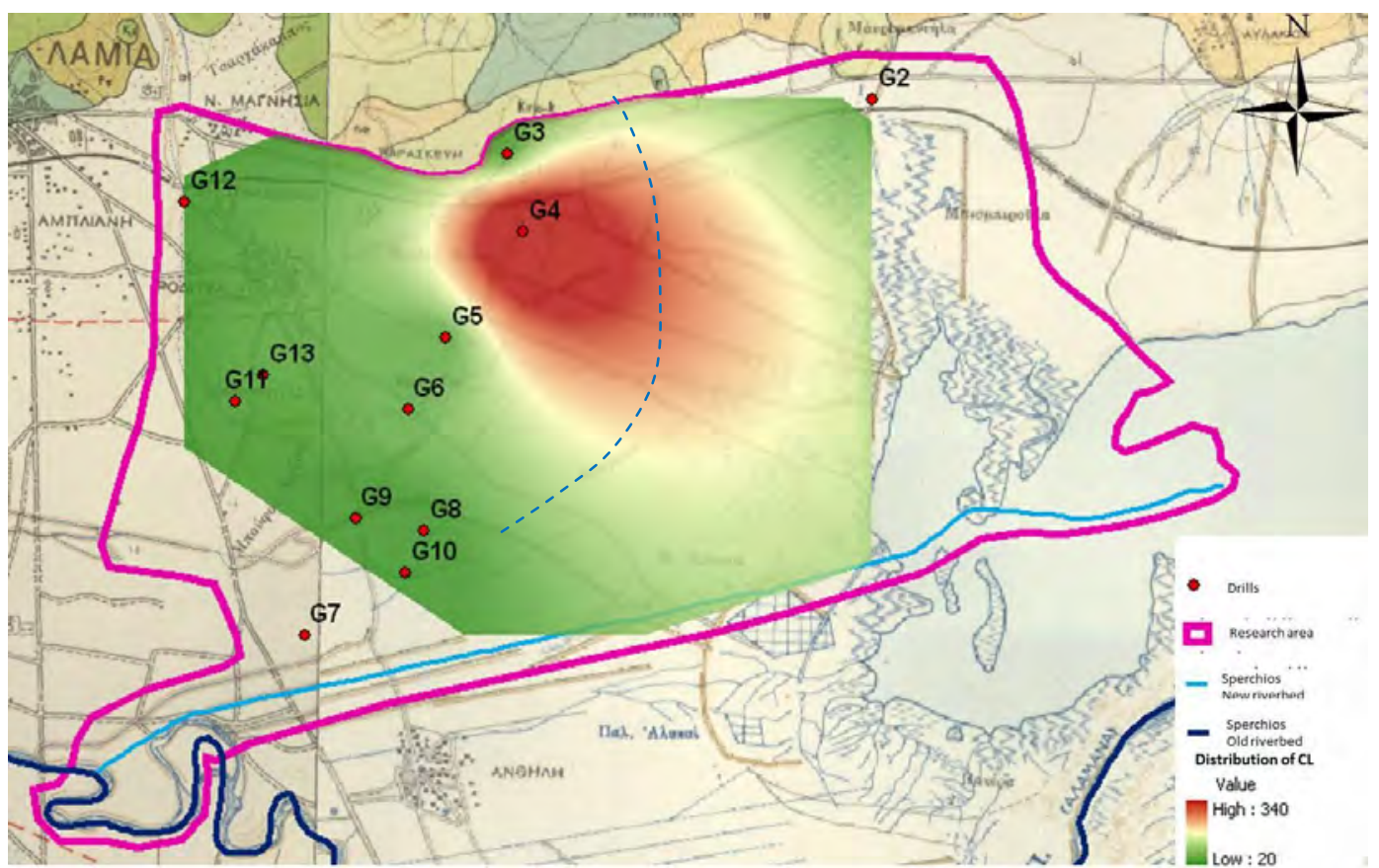

Figure 3 - Distribution map of $\mathrm{Cl}^{-}$in groundwater.

- The increased values of $\mathrm{NO}_{3}$ that were measured in $\mathrm{G} 2$, as well as in the private drillings G11 and G13, which cover the irrigation needs in cultivations south of the settlement, are due to the use of fertilizers (Figure 4). Noteworthy is the combinatorial irrigation fertilization system, in which the fertilizer is put in "tanks", which are connected to the drilling and through the water flow is led to the cultivations. 
The water quality for ten of the drillings is placed, according to SAR index, in the category C2-S1 therefore characterized as of good up to moderate quality (Table 4 - according to Wilcox diagram).The drillings G4 and G13 belong to the category C3-S1, moderate up to very moderate quality (the water can be used under specific conditions).

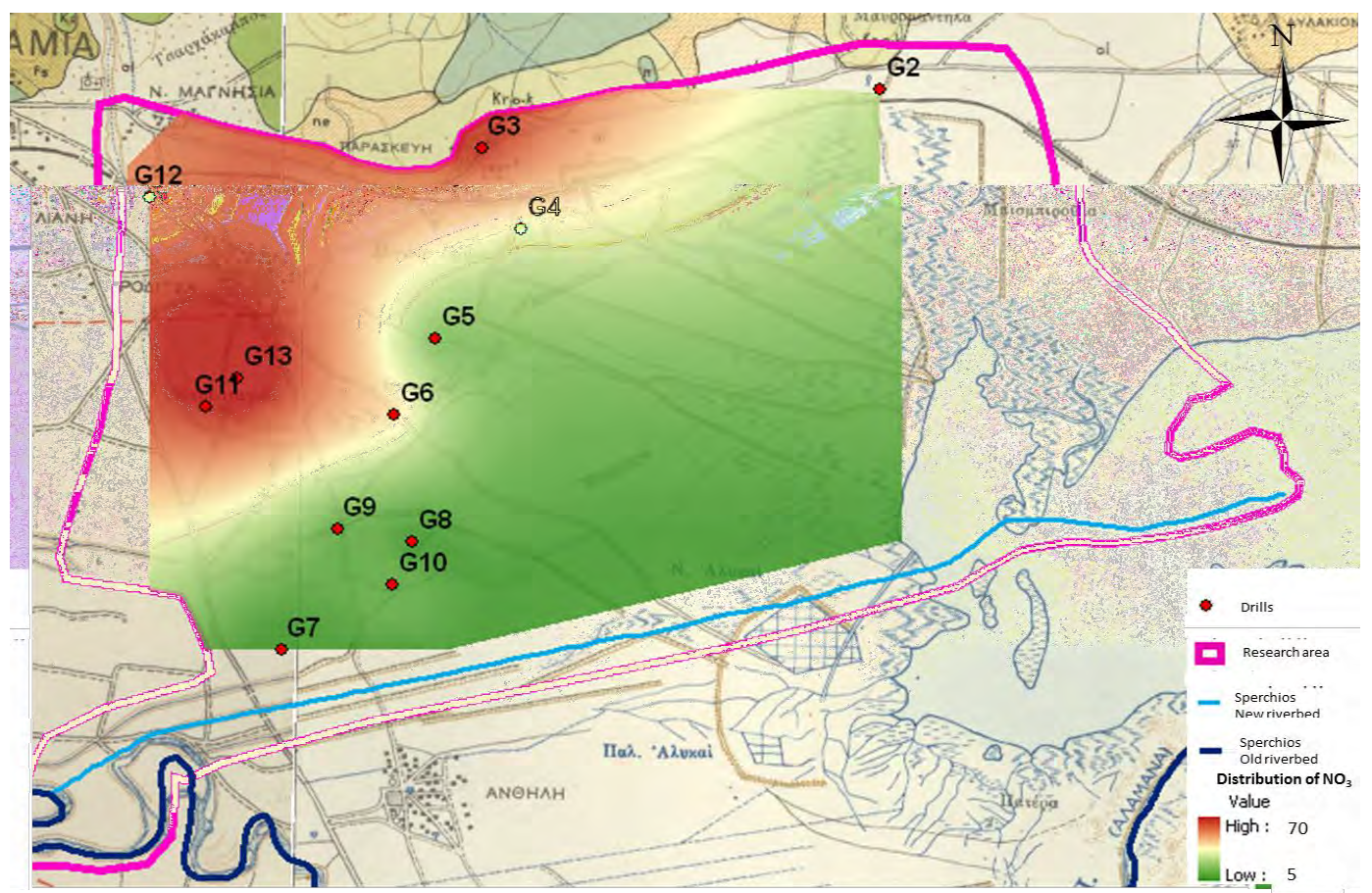

Figure 4 - Distribution map of $\mathrm{NO}_{3}^{-}$in groundwater.

\subsection{Surface Water Quality}

The results from the chemical analyses of surface water are shown in Table 2. In Sperchios old riverbed, the sampling points were Th1, Th2 and Th5.

The samples Th3, Th6, Th10 refer to specific points along the Lamia - German moat. The sampling point Th3 is placed before the moat's junction with Ksirias stream, Th6 east of the national road, before the junction with the Unit of Biological Treatment and finally Th10 in the end of the moat just before its estuary to Sperchios new riverbed - diversion. Sample Th3 has higher concentrations of TDS, $\mathrm{Ca}, \mathrm{Mg}, \mathrm{HCO}_{3}, \mathrm{SO}_{4}$ and $\mathrm{NO}_{3}$ ions, in comparison with the other two samples.

It would be useful to mention that the German moat is a recipient of smaller streams, before Ksirias stream, of the drainage networks of the arable areas such as Komma and Amouri, as well as of these settlement's sewage due to lack of a proper sewage network. The wastes of a local industry also end up in the moat.

The increased value of $\mathrm{Cl}$ ions, in sampling point $\mathrm{Th} 10$ in the end of the German moat, just before the junction with Sperchios new riverbed, must also be noted. The sample Th4 was taken from Ksirias stream, before the junction with Lamia - German moat.

The water of Ksirias stream does not burden the moat's water, as its chemical characteristics are of better quality compared with the ones it meets. This fact is confirmed and by the in situ observations of the natural characteristics of the samples Th3 and Th4 during the sampling. The 
sample Th3 showed increased turbidity, high viscosity, intense stench and green colour. On the contrary the main characteristic of sample Th4 was the increased turbidity.

The increased values of TDS ( $>1000 \mathrm{mg} / \mathrm{l}$ - saline or brackish water), as well as of the ions $\mathrm{Na}$ (Figure 5) and $\mathrm{Cl}$, are data showing salinization (Figure 6), fact that is attributed to intrusion of the sea front inwards the estuaries of Sperchios new riverbed. Comparing the two sampling points Th10 and Th11, it is noticed that the German moat's water that ends up to the new riverbed diversion (Th10) has increased values of TDS as well as of ions $\mathrm{HCO} 3$ and $\mathrm{Cl}$, relatively with the sample of Sperchios new riverbed (Th11).

Sample Th8 was taken by the moat that gathers the pumping station's water and directs it to the sea. All waters of the drainage network of the area's cultivations end up in there. The chemical analysis shows particularly increased values of TDS (the highest measured value among all the surficial samples taken), as well as in all ions except $\mathrm{NO}_{3}$. Noteworthy are also the high values of $\mathrm{Cl}$ and $\mathrm{SO}_{4}$. It is relatively safe to attribute these high concentrations in the effect of seawater, as the sampling point has a distance of about $1 \mathrm{~km}$ from the sea. Sample Th7 was taken from the karstic springs of Megali Vrusi.

The water from the springs presented the highest measured value of $\mathrm{NO}_{3}$ among all the surficial samples. The increased concentration of $\mathrm{NO}_{3}$, is probably due to the neighbouring cemetery, as well as to the sanitary landfill waste site located north of Megali Vrusi springs, in the area of Agia Paraskevi.

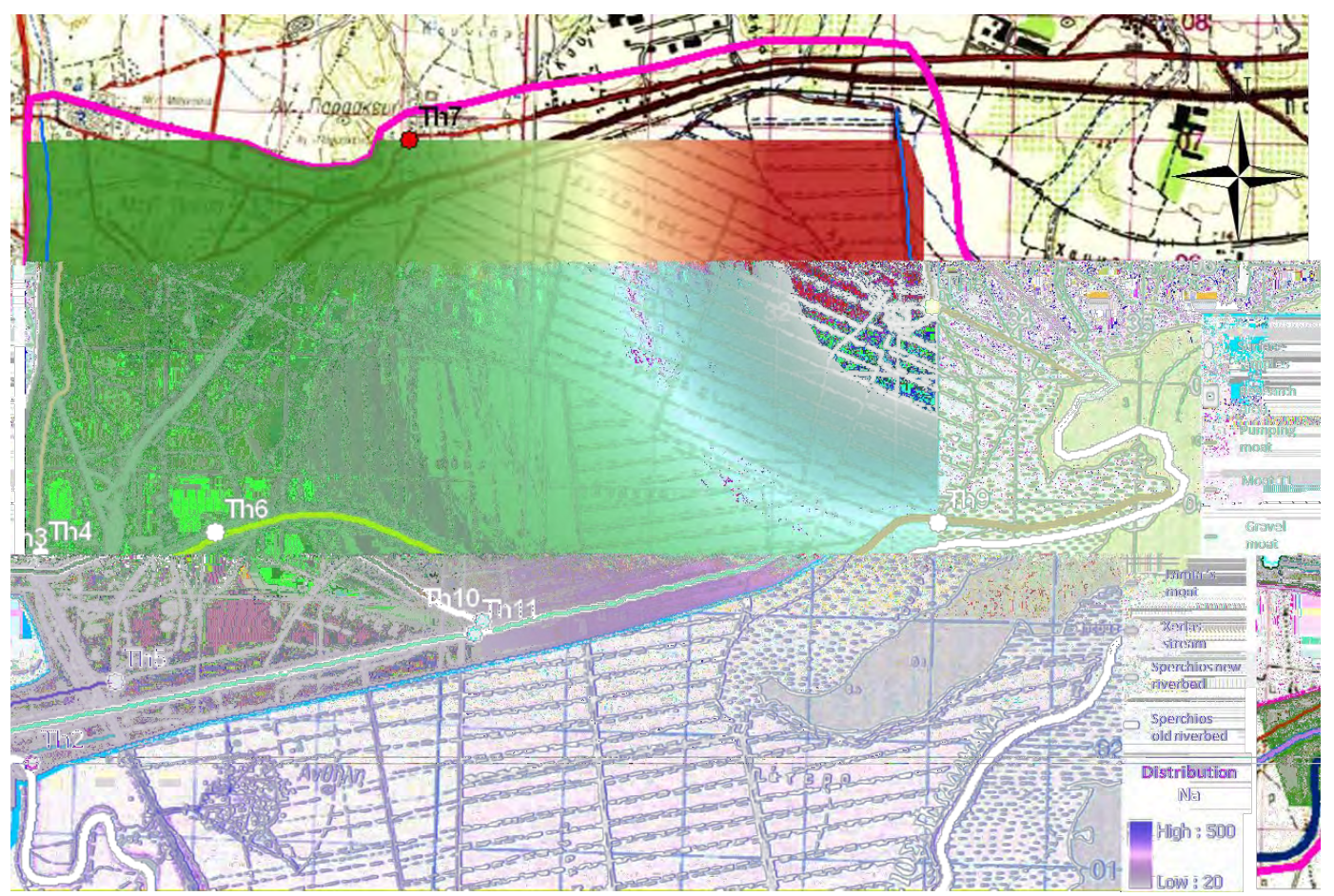

Figure 5 - Distribution of $\mathrm{Na}$ in surface waters.

According to Table 4 and the categories of irrigative water, it is observed that the surficial water of seven samples belongs to the category $\mathrm{C} 2-\mathrm{S} 1$, meaning that their quality is from good up to moderate. Samples Th3, Th9, Th10, belong to the category C3-S1, meaning that their quality is from moderate to very moderate. Finally sample Th8 is of very bad quality (category C4-S3) and should not be used in any case. 


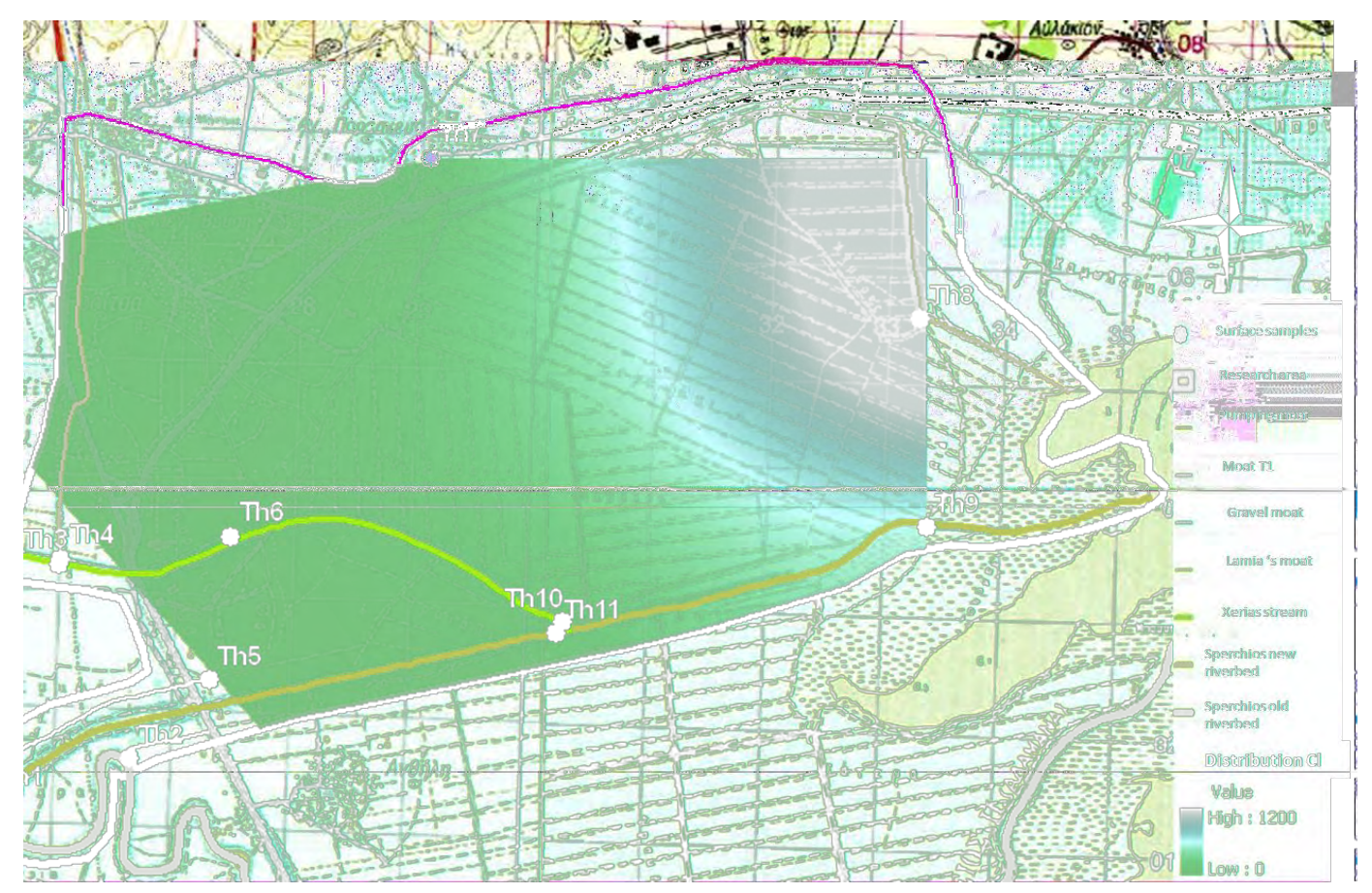

Figure 6 - Distribution of $\mathrm{Cl}$ in surface waters.

Table 4 - Classification of Wilcox diagram.

\begin{tabular}{|c|c|c|c|c|c|c|c|}
\hline $\begin{array}{l}\text { Sample ID } \\
\text { timdergyatuat }\end{array}$ & Station ID & WILCOX CLASSIFICATION & QUALITY & \begin{tabular}{|l|}
$\begin{array}{c}\text { Sample ID } \\
\text { (surface water) }\end{array}$ \\
\end{tabular} & Station ID & \begin{tabular}{c|} 
WILCOX \\
CLASSIFICATION
\end{tabular} & QUALITY \\
\hline G2 & $\begin{array}{l}\text { Maviamadila } \\
\text { Agia Paraskeví }\end{array}$ & st & GO00 TO MODERA & \multirow{10}{*}{\multicolumn{4}{|c|}{ 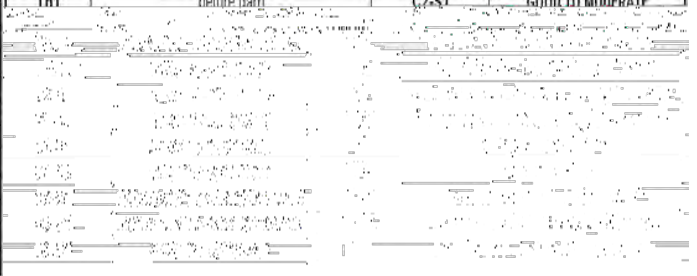 }} \\
\hline $\begin{array}{l}\text { G3 } \\
\text { G4 }\end{array}$ & $\begin{array}{l}\text { Agia Paraskevi } \\
\text { Stergiopoulou }\end{array}$ & Q3.51 & $\begin{array}{l}\text { G000 TO MODERATE } \\
\text { MOOERATE TO VERY MOOERATE }\end{array}$ & & & & \\
\hline G5 & Xatzikosta & $\theta_{2}$ & GOOO TO MODERATE & & & & \\
\hline G6 & ia & 51 & 00 TO MOD & & & & \\
\hline GT & Frelies & & G000 To & & & & \\
\hline 68 & Zardas a & & $6000 \mathrm{~T}$ & & & & \\
\hline G9 & Stathopoulos & 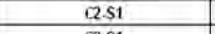 & GOOO TO MODEF & & & & \\
\hline G10 & Kontos a & Q.S1 & GOOD TO MODERATE & & & & \\
\hline$\frac{G 11}{G 12}$ & $\frac{\text { Kontos b }}{\text { os Partelein }}$ & Q.Si & $\begin{array}{l}\text { G00D TO MODERATE } \\
\text { G000TO MODERATE }\end{array}$ & & & & \\
\hline G13 & Zardas b & GSt & MODERATE TO VERY MODERATE & & & & \\
\hline
\end{tabular}

\section{Results and Discussion}

Based on the existent water conditions in the area, the exploitation of the surficial water is considered to be imperative. The karstic springs of Megali Brysh can contribute up to a very important level. In the non-irrigative periods, the water from the spring through canals ends up in the pumping station and from there to the sea in Maliakos Gulf. Storing these water quantities will have a double benefit. This supply will be available during the summer period covering the water shortage and in addition it could be used for artificial enrichment of the area's aquifers. Therefore the over-pumping will be reduced, thus protecting the groundwater reserves, increasing also at once their quantity with the help off the artificial enrichment.

The construction of small containment dams along Ksirias stream watercourse is also suggested, so that new water reserves will be gathered, able to be used for covering the irrigative needs of Roditsa and Megali Brysi settlements, as well as for artificial enrichment of groundwater. These small dams can also withhold the sediment yield of the stream.

The adoption of more efficient irrigative methods would help in a more rational management of the area's water resources. The "drop" irrigative method has the highest degree of efficiency 
$(90 \%)$ and a variety of other advantages, such as the decrease of water loss due to minimum surficial runoff. Furthermore, this method works with low energy cost, due to low pressure requirements and because is unaffected by the wind.

The application of a new pricing policy for the consumers would help in the reduction of pressures in the area's water resources. The cost of irrigative water should be calculated based on water consumption and not based on the cultivated acres.

The constant briefing of producers and farmers, as well as the promotion of specific actions, that will contribute in the acquisition of the proper culture over the subject of rational exploitation of irrigative water, will induce important results. The "cultivation" of a saving philosophy concerning the water resources, followed by the encouragement for adopting new methods (such as the construction of common private drillings, proper pumping and irrigation in specific daily hours, thus minimizing the water losses), targeting towards the reduce of over-pumping of groundwater and in general the inappropriate water use.

The reuse of urban waste for irrigation purposes, with the requirement of completion of trustworthy studies and of all the procedures and their implementation according to the environmental terms, it would probably be an effective solution for the decrease of pumping for irrigation purposes.

\section{References}

Dasenakis E., Kastritis A., Mpourou P., Paraskevopoulou B. and Triantafullaki S. 2005. Transport of pollutant in Sperchios basin and the effects in the coastal zone. 5th National Conference: Integrated Management of Water Resource in a basin.Xanthi

Dimitressas D. 1999. Hydrogeological Study-Water balance in the region of water subtraction in Roditsa -M.Vrusi - Avlaki. Lamia, Geological department, DEB Fthiotidas

Katsifa D. Maria. 2011. Water resources within the area of Roditsa Delta of Spercheos river of Fthiotida county, with emphasis on hydrochemistry and quality, Master thesis, NTUA.

Municipal Water and Sewerage Company of Lamia (M.W.S.C.L), Land Reclamation Institute (LRI)-National Agricultural Research Foundation - (NAGREF) 2009, Study of the environmental effects for the use of treated waste waters from the treatment unit of Lamia for irrigation reasons, Lamia.

Papadimitriou N. 2010. Study for the work Irrigational net of Sperchios estuary Company of Fthiotida's development.

Tsoumas B. 1991. The provision of brackish areas in the peripheral zone of Maliakos - causes of contamination of surface and groundwater to the Maliakos bay, Paper presented at the $2^{\text {nd }}$ Conference Fthiotida prefecture.

Tsoumas B. and Zorapas B. 2010.Recording on the groundwater data of Eastern Sterea Hellas, Infrastructure and Measurement in the catchments of Evritania, Fokida and Fthiotida Hydrogeological study IGME, Athens.

Tsoumas B. and Zorapas B. 2010. Recording on the groundwater data of Eastern Sterea Hellas. Infrastructure and Measurement in the catchments of Evritania, Fokida and Fthiotida Hydrogeological study-Field measurements, IGME, Athens. 